\title{
Terms of Trade Movements and the Global Economic Crisis: Implications for the Asia-Pacific Region
}

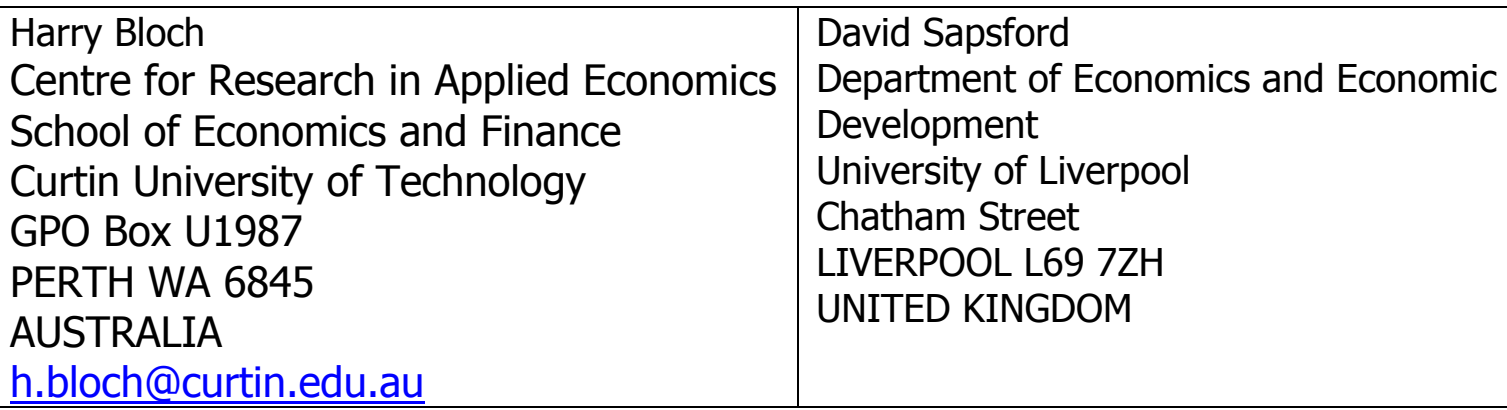

David Sapsford

Department of Economics and Economic

Development

University of Liverpool

Chatham Street

LIVERPOOL L69 7ZH

UNITED KINGDOM

\section{ABSTRACT}

Dramatic changes in the relative prices of goods in international trade have accompanied, and indeed preceded, the global crisis. These changes are reflected in the terms of trade of individual countries and in the relative prices of goods within those countries. Asia-Pacific countries are particularly affected by the changes in relative prices as they have been at the core of the increasing globalisation of production and distribution systems. An analysis of the causes and effects of the relative price changes is developed based on applying the analysis of business cycles developed by Joseph Schumpeter. Schumpeter's analysis emphasises innovation and structural change, particularly creative destruction, which impart uneven development on the economy and can foster financial crises. By applying Schumpeter's analysis the current crisis is put in the context of long-wave development of the capitalist system, which leads to predictions about the likely path of price and output changes over the medium term of the next decade or two.

\section{Key Words}

Terms of trade, Global economic crisis, Schumpeter, Primary commodity prices, Business cycles

\section{JEL Codes}

D24, Q33, Q41

Financial support from the Australian Research Council is gratefully acknowledged. Maria Mangano and Shuddhsawtta Rafiq provided excellent research assistance. The authors take full responsibility for errors and omissions. 


\section{GFC or GEC?}

Most discussion of the dramatic recent developments in the world economy refers to the global financial crisis (GFC). Subtly, the organizers of this conference use the terminology, global economic crisis (GEC). The proposition put forward in this paper is that there is substance to the distinction in terminology. Indeed, we propose that there are factors outside the financial markets that provide a related, but distinct, explanation of the massive dislocations experienced by the world economy.

Our explanation for the GEC focuses on the sharp movements in the relative prices of internationally traded goods that occurred before and during the GFC. In particular, during the commodity boom from 2002 to 2008 there were historic rises in the prices of primary commodities in international trade relative to prices of traded manufactures. This was followed by an equally historic collapse in relative prices. These relative price changes were reflected in the terms of trade of individual countries, albeit to different degrees and direction depending on the composition of their exports and imports. Countries of the AsiaPacific region provide particularly fertile examples because of their central role in the structural transformation, their heavy exposure to trade and the substantial differences across countries in the commodity composition of their trade.

Relative price shocks, particularly shocks to the price of oil, have been given prominence in many discussions of macroeconomic developments in the half century leading up to the GEC (see Hamilton, 2008 for a recent survey). Schumpeter (1939) provides a theoretical framework and historical overview of earlier business cycles, emphasising the role of price movements following on major innovations in the world economy. Interestingly, Schumpeter views financial crises as ancillary to the dynamics of adjustment to innovation, with such crises being a likely, but not necessary, feature of the downswing of the long wave he associates with adjustment to innovations.

Schumpeter's framework provides the basis for the analysis of the dramatic events in the world economy over recent years. Putting the analysis in the context of a long wave of economic development provides a deeper explanation of the global crisis than does financial excess or a housing price bubble. Importantly, it provides a basis for understanding the differential impact of the crisis on different countries and for predicting the path of future developments.

Before expounding Schumpeter's framework and applying it to the global crisis, we first review the past decade of dramatic changes in relative prices of internationally traded goods and show their connection to the terms of trade for selected countries in the Asia-Pacific region. This demonstrates the extent of the shocks to the goods-producing sector of the world economy and provides a background for discussing a framework that emphasises innovations in the production and distribution of goods, both primary and manufactured, as drivers of the long wave of economic development and the accompanying periodic economic crises. Our discussion of the future prospects for the world economy, especially countries in the Asia-Pacific region, follows on from the application of the Schumpeterian framework to the GEC.

\section{Recent Developments in Real Commodity Prices, Terms of Trade and I ndustrial Production}

The last few years have seen swings in the prices of primary commodities. These swings have been much more pronounced than the corresponding swings in prices of manufactured 
goods, resulting in substantial variation in the relative price of primary commodities. The relative price as given by an index of prices of primary commodities divided by an index of prices of manufactured goods is commonly referred to as the real price of primary commodities. Figure 1 shows the International Monetary Fund (IMF) monthly index of prices of primary commodities along with the corresponding unit value index for manufactured goods in international trade. The ratio of these two price indexes is also shown as the real price of primary commodities.

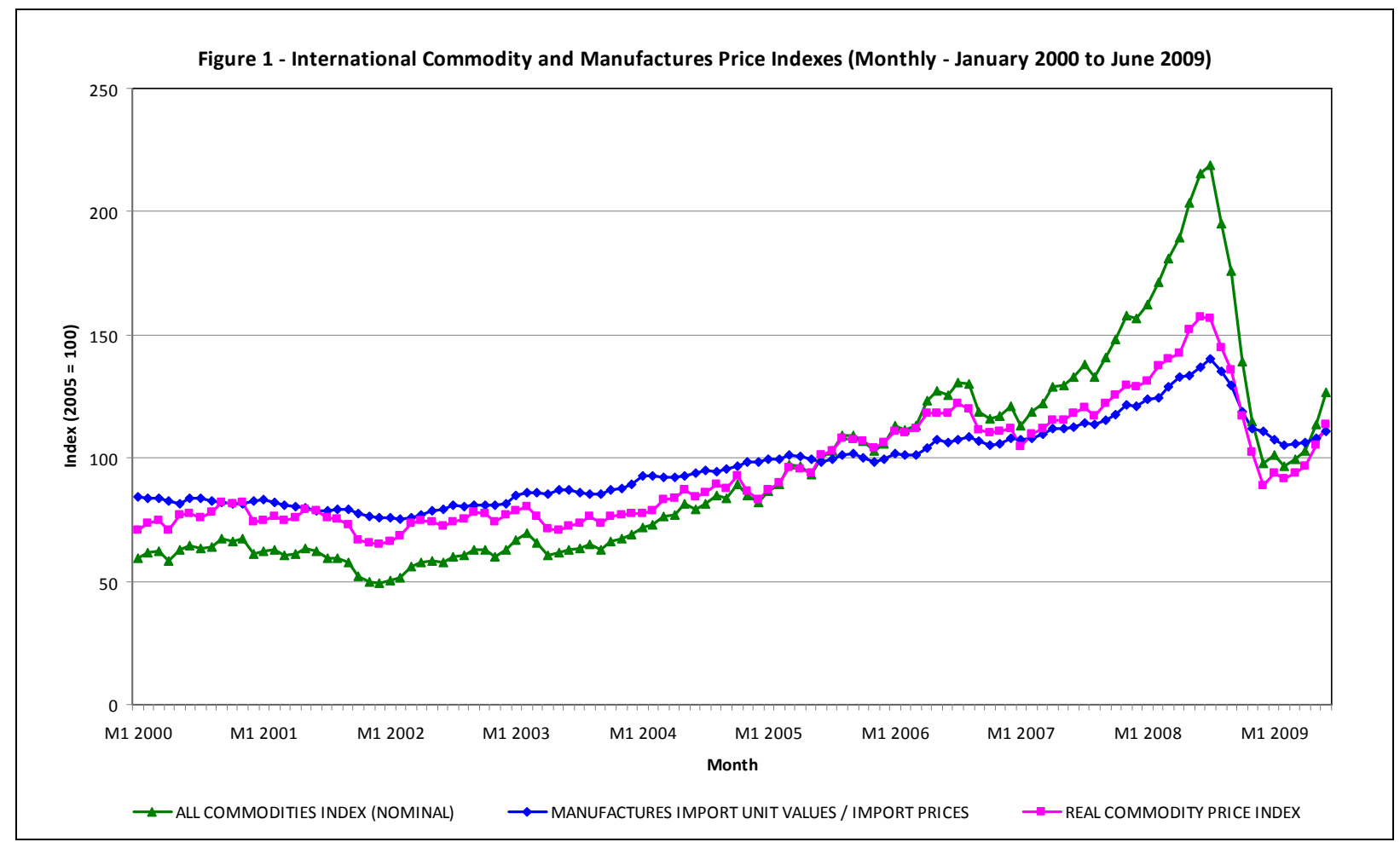

Source: International Financial Statistics - Online

To put the recent movements in perspective, Figure 2 shows movements in annual series for primary commodities and manufactured goods over the period since 1955 . While the commodity price index fluctuated substantially in the 1970 s and early 1980 s, the recent swing is two to three times as large. When changes in the real commodity price are compared to those in data covering the period back to 1650, the recent gyration appears as to be of a historically unprecedented magnitude (see Bloch, Madsen and Sapsford, 2009, Figure 1). 


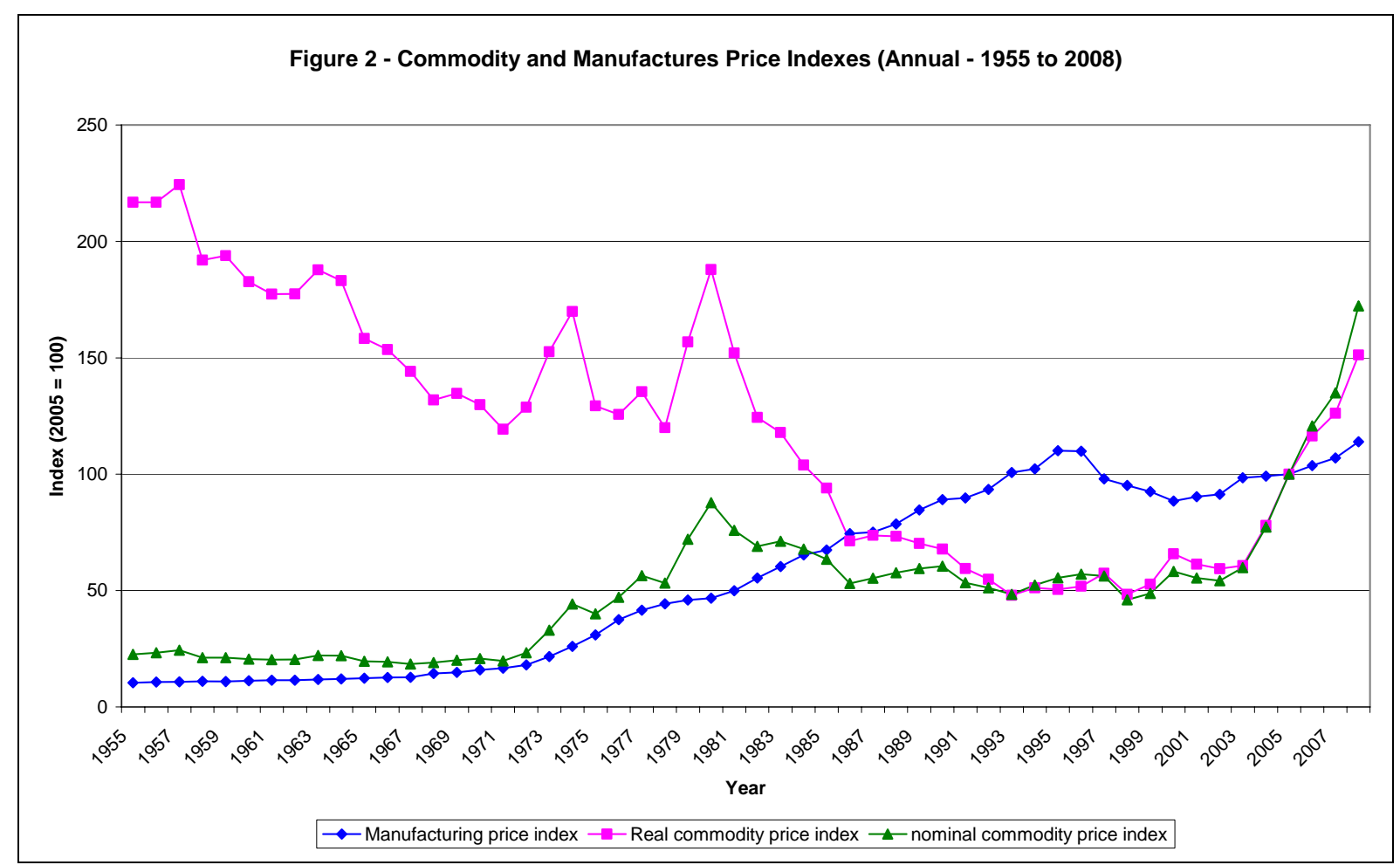

Source: Bloch, Madsen and Sapsford (2009)

The impact on individual countries of swings in international prices of primary commodities and manufactures depends on the commodity composition of their trade. Commodity exporting countries experience a positive change in their trading income when real commodity prices increase, while exporters of manufactures experience a corresponding decline. The reverse effects are felt when real commodity prices drop. The severity of the recent boom and bust in commodity prices means that the impacts on the terms of trade of individual countries (the price index for exports divided by the price index for imports) have been pronounced in extent, even for countries that have mixed composition of their exports and imports over primary commodities and manufactures. An illustration is given in Figures 3 through 5, showing recent movements in the terms of trade for three advanced economies in the Asia-Pacific region, Australia (primarily an exporter of primary commodities), the US (mixed composition of trade but a net exporter of manufactures) and Japan (primarily an exporter of manufactures), respectively. 


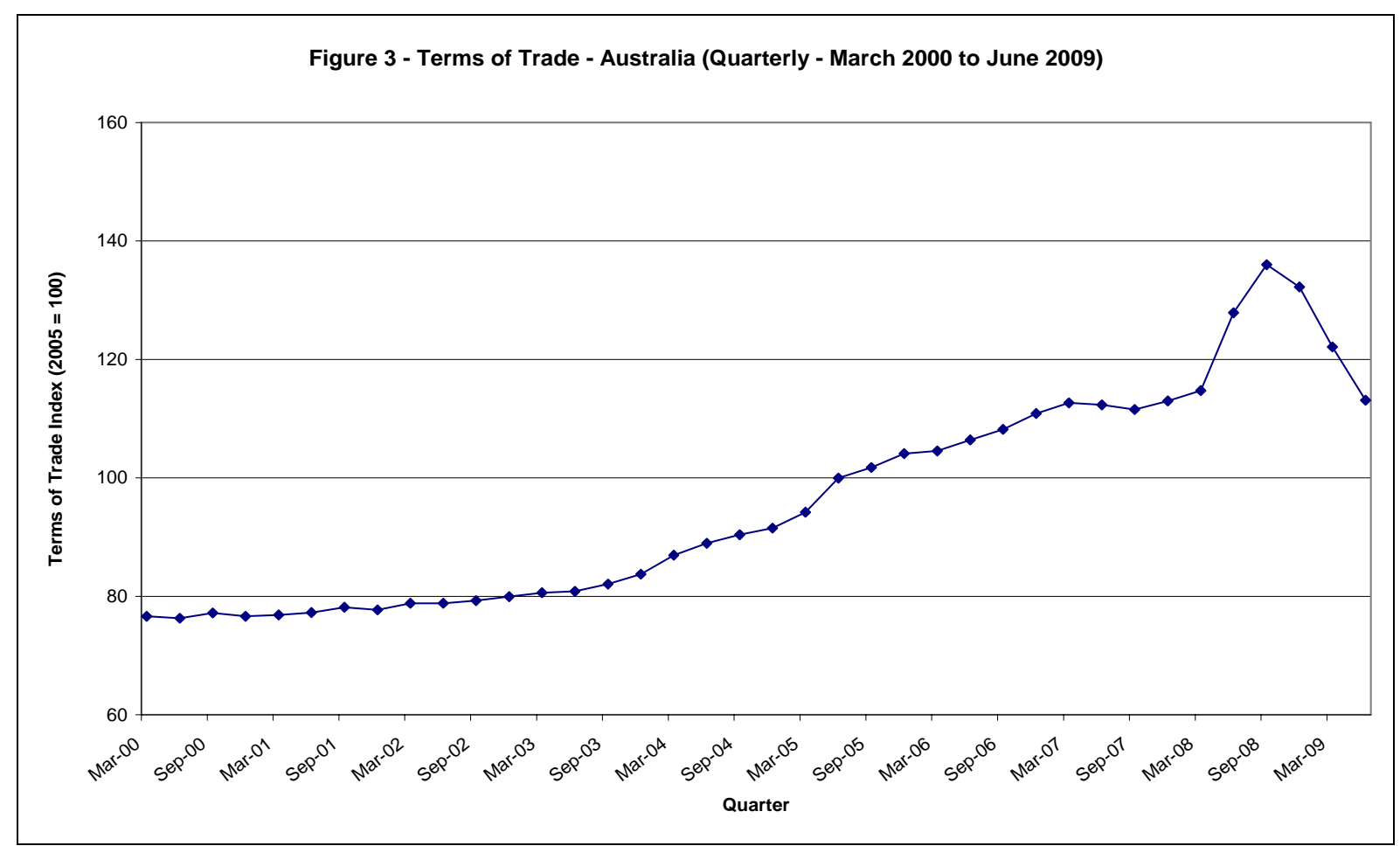

Source: Reserve Bank of Australia

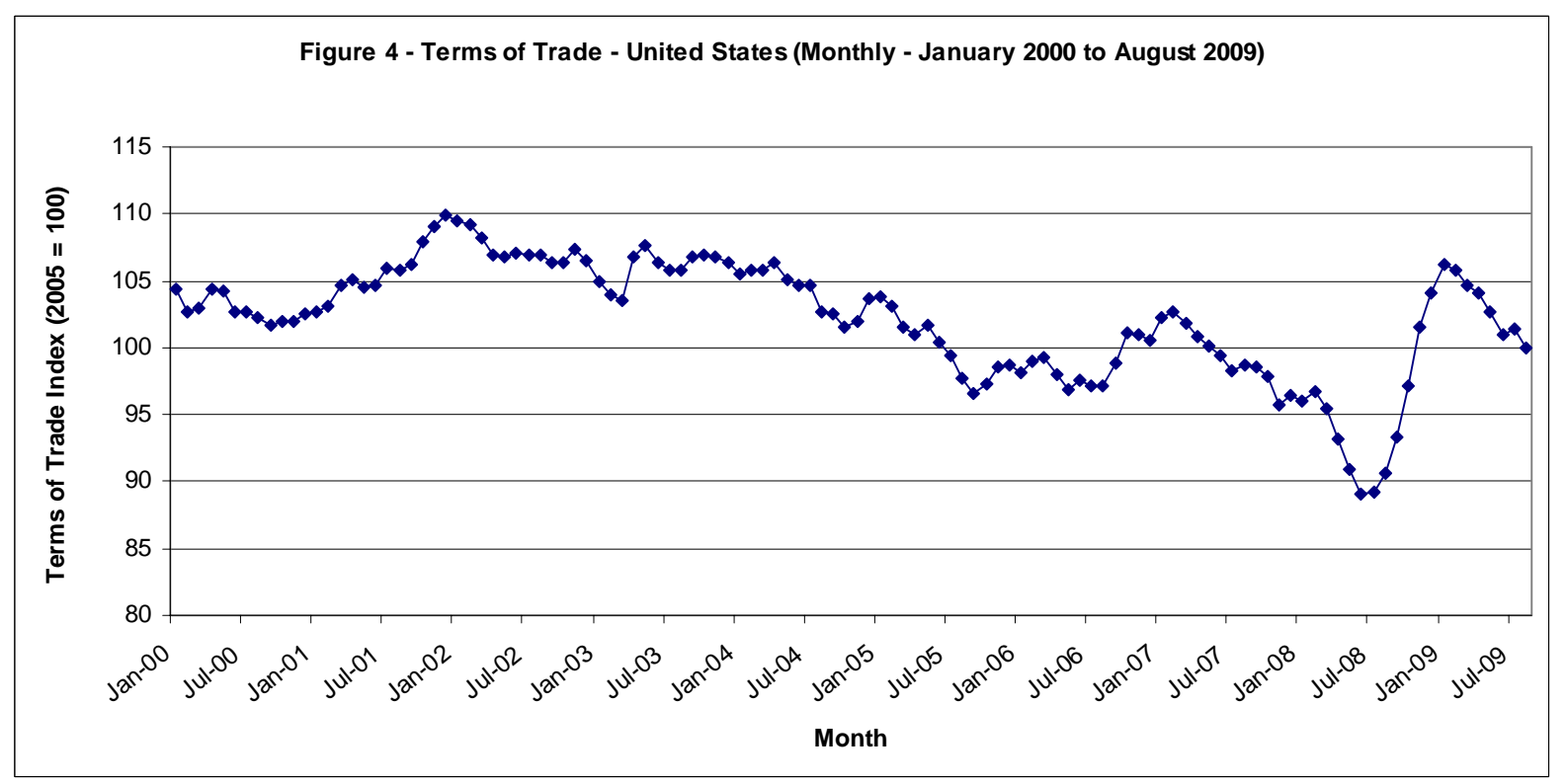

Source: DataStream International 


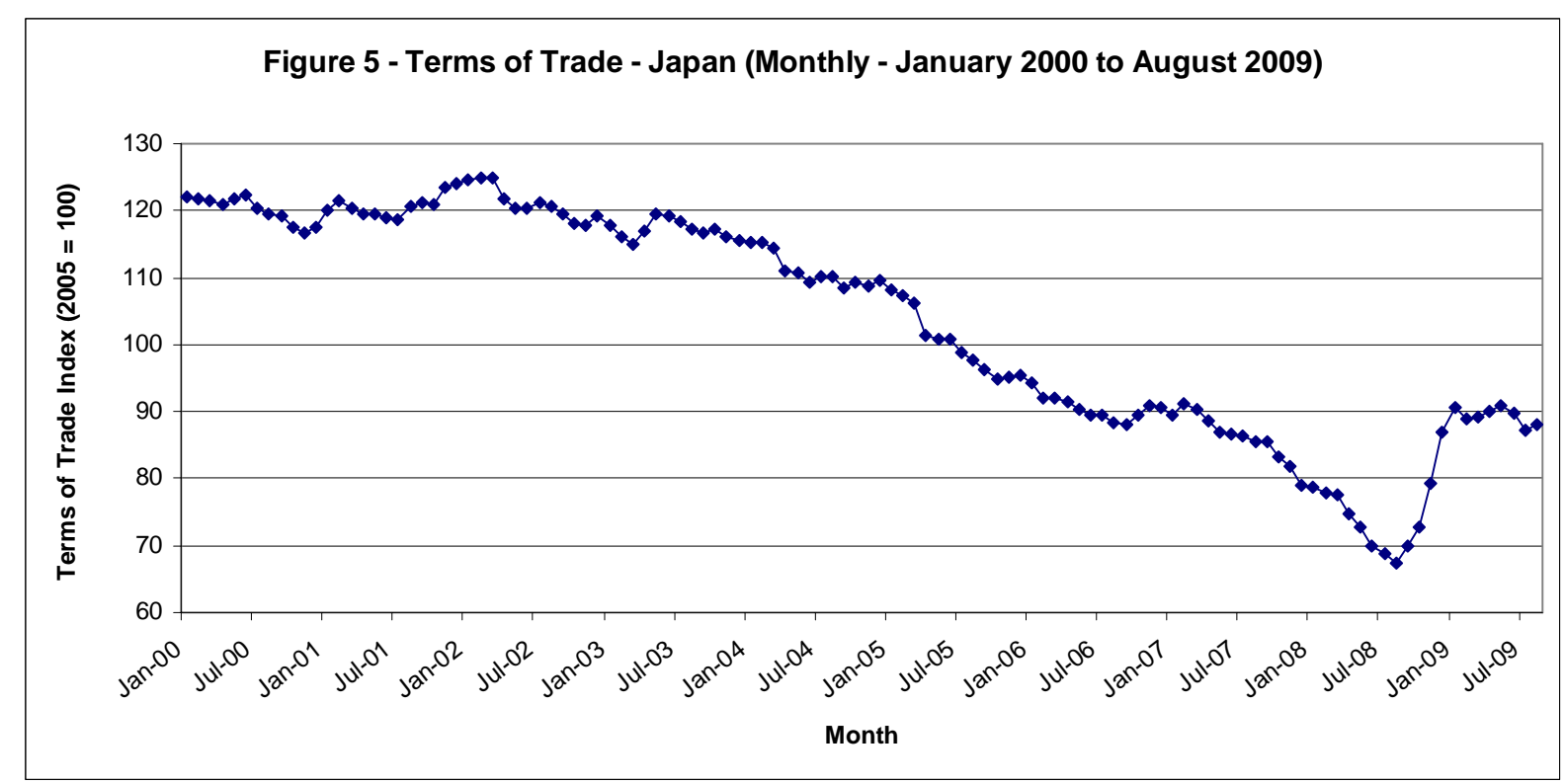

Source: Bank of Japan

Comparison across the figures is complicated somewhat by the difference in reporting frequency, with Australian data reported quarterly rather than monthly as for the US and Japan. However, it is clear that Australia's terms of trade peak around the middle of 2008, while the terms of trade for the US and Japan both reach their trough at around this time. ${ }^{1}$ The magnitude of the fall and rise in the terms of trade for Japan (90 to 67 and back up above 90) greatly exceeds that for the US (105 to 90 and back up above 105), reflecting Japan's greater imbalance in the commodity composition of its imports (largely primary commodities) and exports (dominated by manufactures).

A country's terms of trade affect its trade income and, hence, its trade balance. These can both affect domestic demand, either directly through the impact on the incomes of consumers and businesses or indirectly through government intervention to counter trade balance changes. Changes in domestic demand in turn impact on domestic production even in the most trade exposed countries. Figures 6 through 8 show the pattern of industrial production in Australia, the US and Japan, respectively.

\footnotetext{
1 The terms of trade data reflect shipping lags and the long-term contract arrangements that cover sales of important export commodities, such as coal and iron. Australia's terms of trade are shown as falling in the June quarter of 2009, but monthly data show that the Reserve Bank of Australia's (RBA) all commodities index peaked at 240.7 in November of 2008 and fell to 142.5 in September 2009 (index = 100 in 2001/2).
} 


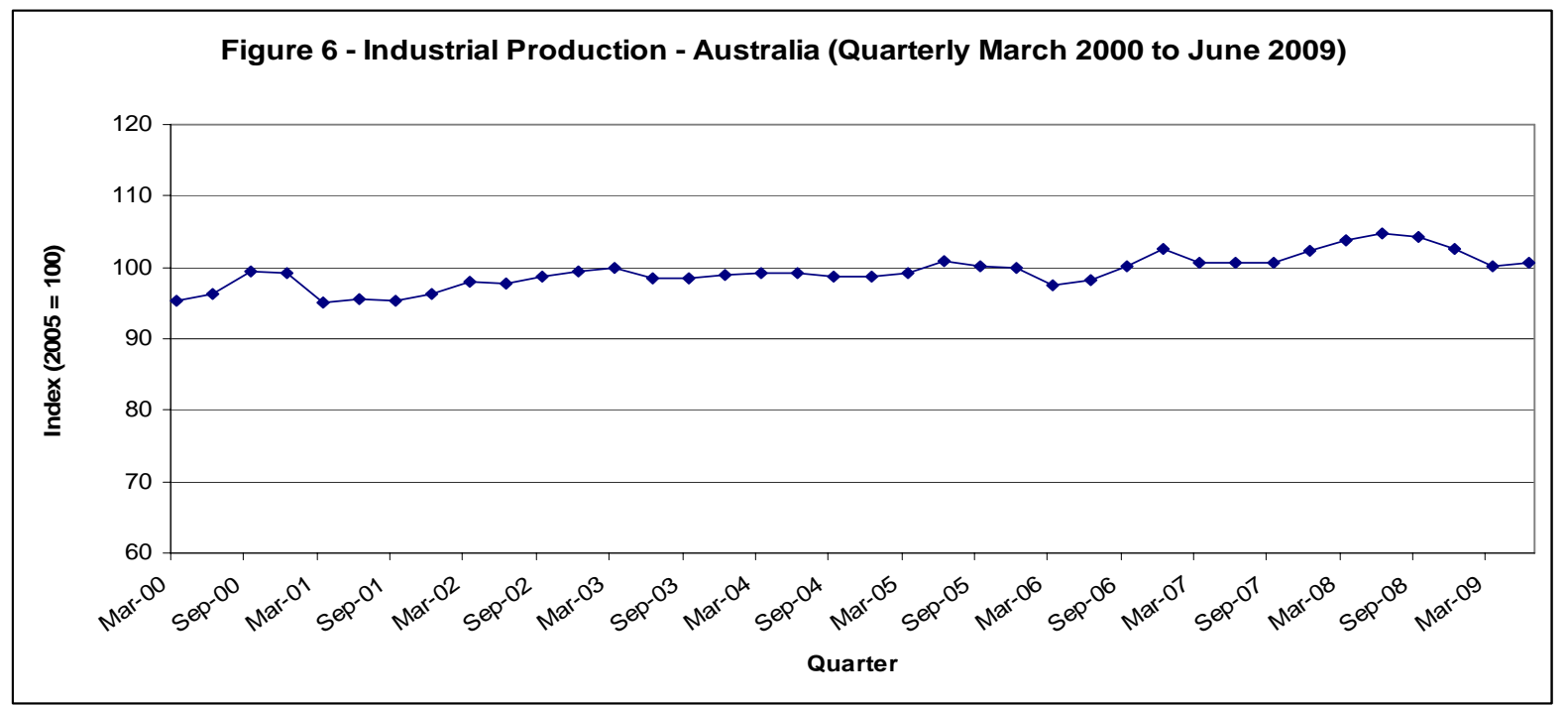

Source: International Financial Statistics - Online

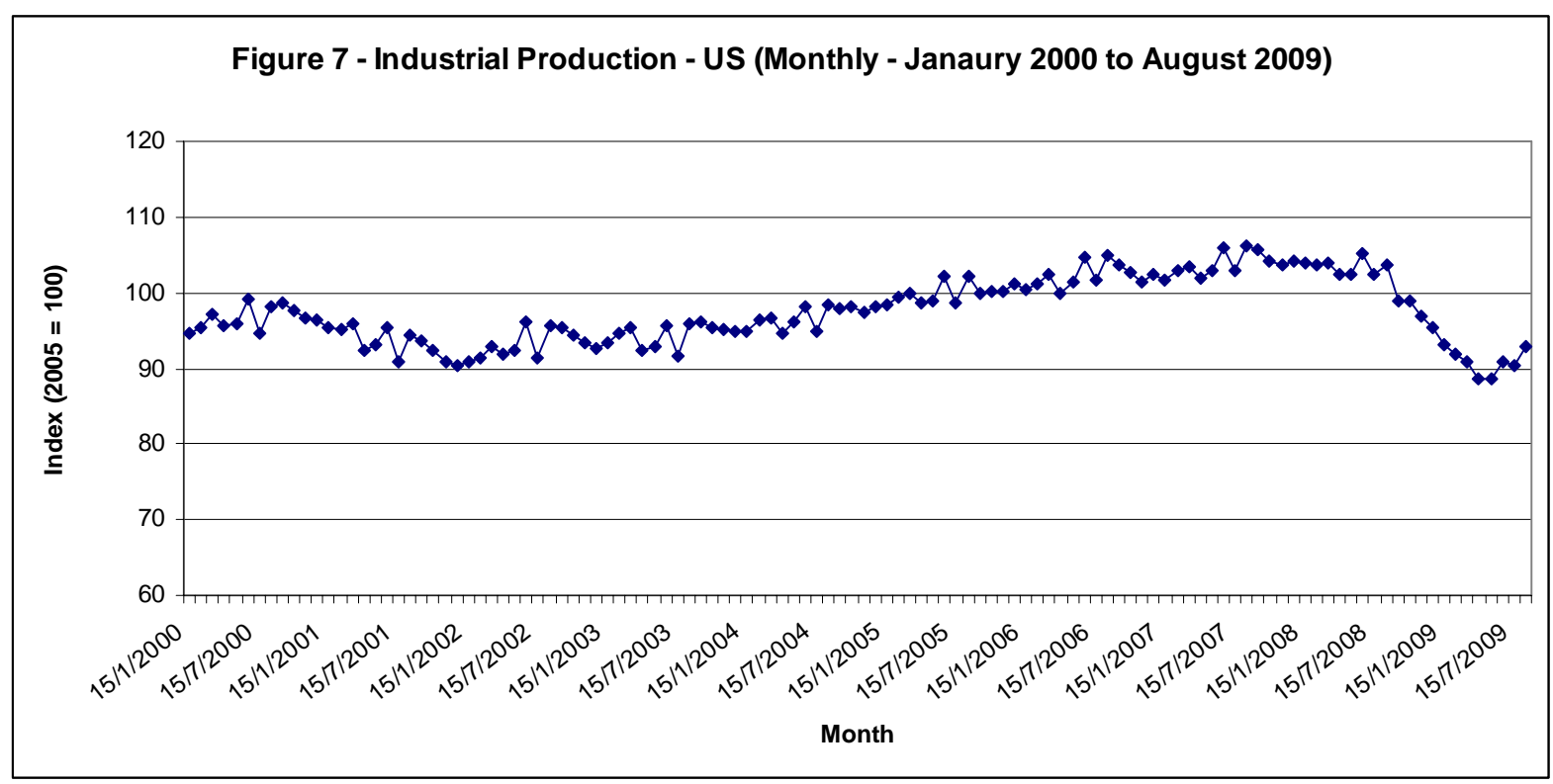

Source: International Financial Statistics - Online 


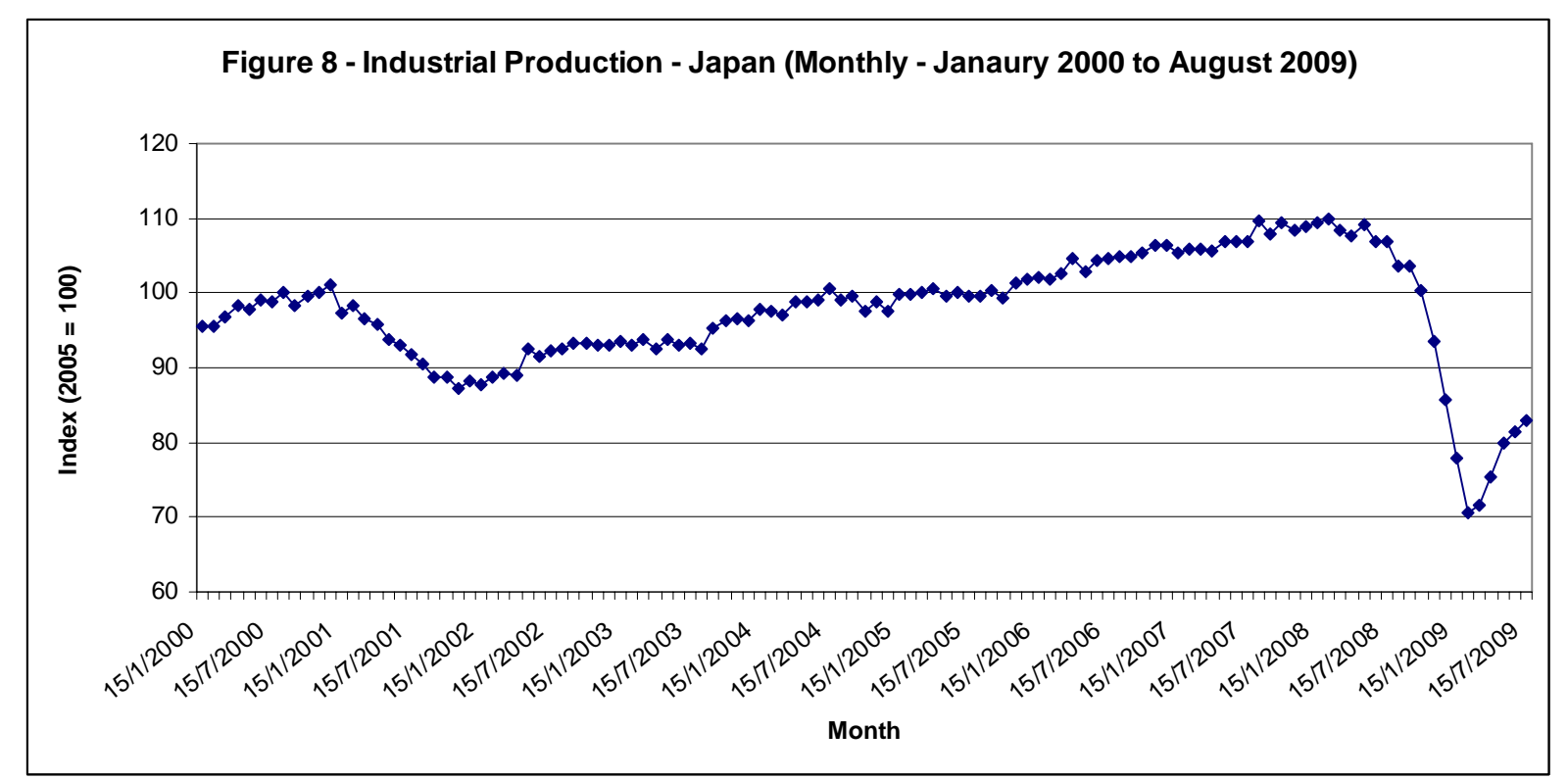

Source: International Financial Statistics - Online

The terms of trade is just one of a myriad of factors that can affect a country's trade income, trade balance, domestic demand and industrial production. Clearly, domestic developments in trading partners are important, especially in heavily trade-exposed countries like Australia and Japan. Yet, the correspondence between the terms of trade movements and industrial production movements for the three countries is readily apparent.

Australia's industrial production in Figure 6 rises until mid 2008 (the peak of the terms of trade in Figure 3) and subsequently declines, although the changes are small. Industrial production for the US in Figure 7 fluctuates moderately without much trend through 2006 and 2007 before falling sharply from mid 2008 and recovering faintly from the second quarter of 2009 (compare to the discussion above of the pattern in Figure 4 for the US terms of trade). Japan's industrial production in Figure 8 is flat from mid 2007 through mid 2008 before plummeting through the first quarter of 2009 and making a substantial recovery (compare to the discussion above of the pattern in Figure 5 for Japan's terms of trade).

It is worth noting that the changes in the direction of the terms of trade in Figures 3 through 5 go back to at least the beginning of 2004 and greatly accelerate in 2007, well before the GFC came to the world's attention. Further, there is some apparent lag between the terms of trade changes and the corresponding industrial production changes in Figures 6 through 8. Chronological precedence is a standard indicator of causality in statistical work in economics, but only causality of a weak form. A convincing argument is required that links recent events to a coherent framework for understanding economic development in the capitalist system. In the next section, we review the framework put forward by Joseph Schumpeter, which is then followed by an argument that shows how the framework applies to the GEC.

\section{Schumpeter's Theory of Business Cycles}

In The Theory of Economic Development (Schumpeter, 1934) sets out the fundamental notion of economic development under capitalism as a process of discontinuous change arising from the actions of entrepreneurs who introduce new products and new production processes, open up new markets and sources of supply of inputs, and carry out new forms of organization of an industry. His Business Cycles (Schumpeter, 1939) then provides the theoretical, historical and statistical flesh to the earlier skeleton. In Business Cycles, 
Schumpeter associates major innovations with each of several long cycles of development in the modern capitalist epoch. In particular he identifies the period from 1786 to 1842 as a cycle associated with the First British Industrial Revolution, the period from 1842 to 1897 as a cycle associated with "railroadization", and an incomplete (at the time of writing in 1938) cycle from 1897 associated with electrification.

In addition to these long cycles lasting between 50 and 60 years, noted as Kondratieff cycles, Schumpeter also recognizes the existence of shorter Juglar cycles, which last between 9 and 10 years, and Kitchin cycles, which last around three years (see Schumpeter, 1939, p.213 for a stylized chart showing how the various cycle lengths overlap). The basic structure of each cycle has four phases, prosperity, recession, depression and revival, although for some cycles, especially the shorter ones, there is no clear distinction between recession and depression. Schumpeter is careful to explain in setting out the theoretical schema that external factors, such as wars, natural disasters and political events, lead to irregularities in the cyclical pattern. Accordingly, Schumpeter's analysis of the historical record is based on the separate interpretation of each period in each country and with reference to specific sectors, rather than relying on statistical methods applied to aggregate data.

Importantly, especially in terms of interpreting recent events, the primary indicator that Schumpeter uses to track the cycle is the movement in prices, particularly prices of finished consumer goods. Schumpeter argues that the initial competition for productive inputs in the prosperity phase of the long (Kondratieff) cycle tends to push up prices, especially for products not directly affected by innovation. However, the eventual spread of the innovation eventually leads to aggressive expansion of production in the sectors experiencing innovation, which feeds competition driving down prices. The "creative destruction" resulting from this competition is a necessary component of the structural transformation of the economy induced by innovation. Schumpeter expects prices to be below the corresponding point of the previous cycle, reflecting the productivity improvements associated with innovation. Thus, Schumpeter expects prices of consumer goods to have a downward trend over the full cycle with an initial rise in the initial prosperity phase followed by a larger fall in the recession and depression phases and, perhaps, some recovery in the revival phase.

Critical reviewers of Business Cycles, such as Kuznets (1940), focus their attack on the notion that innovations give rise to business cycles. They argue against the propositions that there is a regular bunching of innovations, that such bunching gives rise to a four-phase business cycle and that there are overlapping Kitchin, Juglar and Kondratieff cycles. Even sympathetic commentators on Schumpeter's basic vision, such as Oakley (1990), find fault with his analytical representation of the cycle. ${ }^{2}$ Yet, the notion that major innovations impart an uneven flow to economic development features prominently in many recent attempts to understand long-run development of the capitalist system (see, for example, Tylecote, 1992, Freeman and Louçã, 2001, and Lipsey, Carlaw and Bekar, 2005). This aspect of Schumpeter's theory is exploited below in our analysis of the GEC, especially the results concerning the impact of structural transformation on direction changes in prices over the long cycle.

\section{Applying Schumpeter's Analysis to the GEC}

\footnotetext{
${ }^{2}$ For a detailed critical discussion of the distinction between the primary and secondary dimensions of Schumpeter's business cycle theory see Oakley (1990), especially Chapters 8 and 9.
} 
From a Schumpeterian perspective, the GEC can be interpreted as a severe episode of the perennial gale of creative destruction following on from major innovations in production and distribution systems that lead to structural transformation in the global economy. In this section, we identify the innovations, point to evidence of the aggressive competition generating creative destruction and discuss the characteristics of the ongoing structural transformation. Importantly, this analysis builds on the data on relative prices and terms of trade presented above.

Fundamentally, innovations leading up the GEC are but the latest chapter in the story of gains from specialisation and the division of labour noted by Adam Smith in 1776 in his The Wealth of Nations. In popular discussion the innovations we identify as central to this chapter are subsumed under the concept of globalisation. Schumpeter's broad conception of innovation applies, with innovations in institutions (particularly multilateral and regional trade liberalisation), organisations (particularly the spread of multinational firms and, more recently, the rise of international strategic alliances and supply chains) and technology (particularly in shipping and ICT systems that foster international supply chains and the development of global markets).

These innovations have fostered the integration of separate regional and national systems into global production and distribution systems. This has allowed the achievement of substantial economies of scale. Partly, the scale economies are internal to production units that have been able to increase in size by serving wider and deeper markets. Partly the economies are external to the individual production units and are due to vertical integration of supply chains or are due to horizontal (or agglomeration) economies arising from spillovers between units producing similar products. Finally, there is a clear efficiency gain associated with the reallocation of production from high-cost to low-cost producers. ${ }^{3}$

Two key questions are why has the group of innovations associated with globalisation led to crisis and why has it occurred at this particular juncture in history? The Schumpeterian answer to the first question is that innovations lead to aggressive competition. The innovators initially account for small market share and are able to expand while maintaining their prices and while earning high profits (profits may even increase as the innovators perfect their production processes and reach efficient scale, driving down costs). This encourages their expansion and the entry of imitators. The expansion of production can be sustained by expanding the market, which means encroaching on the domain of established producers who use more traditional methods. Prices fall due to competition for buyers, and costs increase due to the competition for productive inputs. The established producers become unprofitable and decline or disappear. This is the process of creative destruction. ${ }^{4}$

Who are the innovative producers in the GEC episode of creative destruction? Manufacturers in the newly industrialising countries, particularly in Asia and most recently specifically China, have been particularly important. They have taken advantage of plentiful domestic labour, technology transfer and access to Western markets to build hugely profitable industrial enterprises. ${ }^{5}$ Such enterprises have progressively extended their range of activities from

\footnotetext{
${ }^{3}$ Reallocation yields efficiency gains when it is based on comparative advantage, such as when China exports manufactured goods to Australia and imports primary products.

${ }^{4}$ Schumpeter does not formally model this process, but a similar story with a formal model is told by Steindl (1976). See Bloch (2000) for a comparison of the two approaches to analysing dynamic competition.

${ }^{5}$ Many of the firms involved in this process have been Western manufacturers shifting their production from home markets to the newly industrialising countries, thereby enhancing technology transfer and access to the home market.
} 
simply transformed manufactures, such as clothing, to heavy industry, such as steel, and eventually to elaborately transformed manufactures, such as electronics and motor vehicles.

Who are the established producers faced with decline or extinction in the GEC and its aftermath? As the innovating manufacturers from Asia extended their sales from domestic markets to exports, they have come into competition with Western manufacturers in both third country markets and in the domestic markets of the Western manufacturers. Faced with low-price import competition, Western manufacturers have experienced falling profits and declining market shares, mitigated to some degree by innovative adaptations (including shifting production offshore), nationalist consumer preferences and protectionist interventions by home countries.

The second key question posed above is why has the GEC occurred at this historical juncture? Schumpeter (1939) argues that long cycles in economic development last five to six decades. Creative destruction is most intense in the late stages of the downswing of the cycle, some four to five decades into the initial upswing. If the upswing of the current long cycle dates from the mid 1950s, after the post-war recovery, a bout of intense competitive struggle and creative destruction is due or a little overdue. The struggle between Western manufacturers and their new competitors has reached its climax and the incumbent Western manufacturers are struggling for survival.

On our interpretation, the spike in the real price of primary commodities from 2004 through 2008 as shown in Figure 1 reflects the climax in competition between the new and old forces in world manufacturing. Labour supply has not been a major constraint on the simultaneous expansion of both groups. In Asia, particularly China, the release of labour from agriculture has provided an ample work force for the expansion of manufacturing, and productivity growth in the West has been sufficient to allow expansion with a steady or shrinking manufacturing labour force. Financial capital has generally been plentiful with credit expansion associated with international financial institutions, such as the IMF and World Bank, and this capital has been increasingly mobile internationally. This leaves demand in product markets and the supply of raw materials as constraints on simultaneous expansion. The competition for raw materials has driven up primary product prices, while at the same time competition for market share has lowered manufactured goods prices, at least relative to costs.

Schumpeter (1939) notes that banking crises are a common feature of the latter part of the downswing of long cycles, although he argues that they are not a necessary part of the structural transformation associated with creative destruction. Financial structures built upon the pre-existing economic system become fragile, especially when excesses have flourished in good times. Aggressive price competition reduces income flows and renders worthless debt obligations of some incumbent producers. The GFC has some characteristics that match this scenario, but as Schumpeter (1939, p.34) cautions in discussing the possibility of identifying causation for events within the business cycle, 'each one is a historical individual and never like any other, either in the way it comes about or in the picture it presents.' Thus, it is inappropriate to conclude that the GFC has been caused by the GEC, just as it is inappropriate to conclude the opposite causation.

The GEC and the GFC are interrelated. Each has its own historical preconditions, but each affects and is affected by the other. The timing and severity of the decline in primary commodity prices is undoubtedly influenced by the collapse in world financial markets, just as the preceding spike in commodity prices helped to expose fragility in the financial system. Likewise, the fall in commodity prices helped restore profitability to some parts of the global 
production and distribution system, notably manufactures in China, which helped recovery in financial markets.

\section{Conclusions and Future Prospects}

In this paper we argue that the world has experienced an economic crisis distinct from, but not unrelated to, the financial crisis. The economic crisis is reflected in the sharp rise in real commodity prices from 2004 to mid-2008 and the even more precipitous decline thereafter. We interpret the economic crisis in Schumpeterian terms as a bout of creative destruction, following on from innovations in global production and distribution systems. This creative destruction is part of the structural transformation that has seen a massive shift of manufacturing activity from the West to the newly industrialising countries, especially in Asia, and, most recently, China.

Both the economic and the financial crises are global in nature. Hence, it is appropriate to use the descriptors, global economic crisis (GEC) and global financial crisis (GFC). However, many of the key players in the structural transformation are in the Asia-Pacific region. We illustrate the processes at work with charts showing the terms of trade and industrial production indexes over 2000 to 2009 for three heavily involved countries in the region, Australia, Japan and the US.

An assessment of the short-term prospects for the world economy based on the Schumpeterian approach depends on positioning the current situation in terms of Schumpeter's long cycles. The recent rebound in commodity prices and manufacturing activity, at least among the innovating producers, suggests a revival but does not clarify whether this is a revival in a shorter business cycle or in the long cycle. We speculate optimistically that the climax of the bout of creative destruction has passed and that the world economy has moved into the revival phase of the long cycle.

In the revival phase of Schumpeter's long business cycle, innovation is relatively subdued and prices are at "normal" levels. By "normal" Schumpeter means something akin to the prices in classical long-period analysis or in neoclassical general equilibrium, namely prices that reflect the cost of production without unusual disturbances in input markets. Economic activity is neither depressed nor exuberant

In a revival period, the winners and losers from the preceding process of creative destruction become clear. In the GEC and GFC, the overall decline in asset values and economic activity means that losers abound and winners are difficult to find. However, as the crisis abates more winners should emerge from the structural transformation following on from the innovations to global production and distribution systems. Manufacturers in the West, including their workers and financiers, have suffered already and have, at best, a partial recovery on the horizon. Meanwhile, manufacturers in the newly industrialised countries and China should resume growing, albeit perhaps not at quite the same pace and without the abnormally high profit rates as experienced in the decades leading up to the GEC/GFC. The big winners will be buyers of manufactures, at least in those parts of the world where buyers have access to imported manufactures at world prices.

Where does this leave Australia? As an exporter of primary products, Australia has benefitted substantially from the commodity boom and has experienced falling terms of trade since the GEC/GFC as sown in Figure 3. While commodity prices have recovered somewhat from the depths of early 2009, they are unlikely to return to boom levels. Nonetheless, Australia is well placed in terms of Schumpeterian competition, with innovative production technology 
and transportation systems for much of her primary production. Even with a resumption of the long-run decline in real commodity prices as documented in Harvey, et al (2009), Australian producers should generally remain competitive. ${ }^{6}$

What about other countries in the region? Manufacturing presents a mixed future, depending on whether producers are in the vanguard of innovations in the global production and distribution system or are lagging behind. Most manufacturers in the newly industrialising countries and in China should do well, especially where they are able to combine new equipment embodying frontier technology with relatively cheap labour. Manufacturers in Japan and the US are in a more difficult position, even after restructuring and cost reductions of recent years. They will continue to be challenged in their existing markets by the new entrants and will need to reinvent themselves to prosper over the longer term.

Our appraisal of future prospects is so far limited to conditions associated with the revival phase of a long cycle. The future beyond then depends on the nature and timing of the next major grouping of innovations. As noted above, established manufacturers are under pressure to reinvent their products, processes and markets or face extinction. This may lead to major new breakthroughs in technology. We claim no expertise as futurologists and, hence, offer no speculation as to the nature or timing of the "next big thing". However, we do have confidence that the capitalist system will continue to generate innovations that fundamentally alter the way we work and live, and which should at some point trigger an upswing of a new long cycle in global economic development.

We close with a few observations based on our interpretation of Schumpeter's theory of economic development. First, capitalism occasionally produces a maelstrom in economic life. These events are an inherent part of a system that fosters innovation as the driver of competition in the long run. Governments are under pressure to offset the negative consequences of this competition, especially during the maelstrom. This is appropriate and, indeed, provides a major role for government in modern societies that endeavour to use the fruits of material progress to improve the life of their citizens. ${ }^{7}$ Yet, because cycles are endogenous to the capitalist process, Schumpeter's theory suggests constraints on the scope for policy to ameliorate the undesirable excesses of competition without impeding the working of the process. Particularly important is avoiding policy that interferes with the process of innovation and the subsequent creative destruction. This leaves governments with difficult choices on which they will expect advice from economists.

\footnotetext{
${ }^{6}$ Bloch and Sapsford (2000) estimate that a rate of growth of world industrial production greater than five percent per annum is required for the real price of primary commodities to increase. Otherwise, the long-run trend dominates and real commodity prices fall.

${ }^{7}$ Schumpeter (1939, p. vi) explicitly denies that his analysis in Business Cycles justifies a policy of nonintervention to alter the course of the economic process. An example of policy intervention that survives Schumpeter's disapproval is the US National Industrial Recovery Act of June 1933, which he notes, 'pegged weak spots within industries, stopped spirals in many places, mended disorganized markets, especially in cases of inelastic demand and that of "overproduction" which is incident to the process of underselling the obsolete.' Schumpeter (1939, pp.992-3) He then draws a distinction between situations in which this had impaired industrial transformation and situations where it had avoided wanton destruction (oil and bituminous coal).
} 


\section{References}

Bloch, Harry (2000), 'Schumpeter and Steindl on the dynamics of competition', Journal of Evolutionary Economics, 10, (2000): 343-353.

Bloch, Harry, Madsen, Jakob and Sapsford, David (2009), 'Trend and cycle in primary commodity prices: A neo-Schumpeterian interpretation', paper presented the conference, 'Neo-Schumpeterian Economics: An Agenda for the $21^{\text {st }}$ Century', Trešt, Czech Republic, June.

Bloch, Harry and Sapsford, David (2000), 'Whither the terms of trade? An elaboration of the Prebisch-Singer hypothesis', Cambridge Journal of Economics, 24, 461-481.

Freeman, Chris and Louçã, Francisco (2001), As Time Goes By, Oxford, Oxford University Press.

Hamilton, J.D. (2008), 'Oil and the macroeconomy', in Durlauf, S. and Blume, L. (eds), The New Palgrave Dictionary of Economics, second edition, London, Palgrave Macmillan.

Harvey, David I., Kellard, Neil M., Madsen, Jakob B. and Wohar, Mark E. (2009), 'The Prebisch-Singer hypothesis: four centuries of evidence', Review of Economics and Statistics, forthcoming.

Kuznets, Simon (1940), 'Schumpeter's Business Cycles', American Economic Review, 30, 25771.

Lipsey, Richard G., Carlaw, Kenneth I. and Bekar, Clifford T. (2005), Economic Transformations, Oxford, Oxford University Press

Oakley, Allen (1990), Schumpeter's Theory of Capitalist Motion, Aldershot UK, Edward Elgar.

Schumpeter, Joseph A. (1934), The Theory of Economic Development (translation of second German edition by Redvers Opie), London, Oxford University Press.

Schumpeter, Joseph A. (1939), Business Cycles, Volumes 1 and 2, New York, McGraw-Hill.

Steind, Josef, Maturity and Stagnation is American Capitalism, New York, Monthly Review Press.

Tylecote, Adnrew (1992), The Long Wave in the World Economy, London, Routledge. 